\author{
Sylwia Różycka-Jaroś \\ Uniwersytet Warszawski \\ s.rozycka-jaros@uw.edu.pl
}

\title{
Sytuacja prawna dzieci w Polsce po 1945 r. Wybrane aspekty z A.S. Makarenką w tle
}

\section{Summary}

The legal situation of children in Poland after 1945. Selected aspects from A.S. Makarenko in the background

The time after 1945 is one of the most important moments in the process of developing children's rights, because for the first time in the history of Polish legislation the established law had equalized the legal position of all children, abolishing all differences between those who were born in and outside of marriage. The analysis carried out in the text shows that the law established at that time was not only progressive in relation to the past, but it also kept up to date, about which, after the liberal breakthrough of 1989, we do not want to remember. The developed principles of exercising parental authority, with parents' rights and duties equated, caused the concept of the child welfare to play a leading role in the interpretation of family law. The child welfare has therefore become the basic value that requires priority treatment. It is also important that after 1945 the process of eliminating children's corporal punishment from the pre-school and school environment, and now also from the family circle, was initiated.

Słowa kluczowe: prawo rodzinne, dobro dziecka, władza rodzicielska, wychowanie, karanie

Keywords: family law, child welfare, parental responsibility, upbringing, punishing

\section{Wstęp}

Analiza dotycząca sytuacji prawnej dziecka w Polsce po 1945 roku sytuuje się w wielowątkowej, interdyscyplinarnej dyskusji podjętej podczas konferencji „W świetle i cieniu idei Antona Makarenki”, a jej celem jest zrekonstruowanie kontekstu historycznego, w którym system pedagogiczny stworzony przez Niego oddziaływał m.in. na polską powojenną rzeczywistość. Trudno przecież myśleć o systemie wychowania dziecka w całkowitym oderwaniu od prawa, które nierzadko, w większym stopniu niż głoszone myśli pedagogiczne, kształtuje pozycję dziecka w społeczeństwie. Idee głoszone przez Makarenkę nie miały bezpośredniego wpływu na polskie regulacje prawne, ale ustawodawstwo wówczas stworzone pozostawało w strefie silnego wpływu radzieckiego prawa familijnego, które podobnie jak dorobek Makarenki w pedagogice, na kolejne dekady zdeterminowało sytuację prawną dziecka. 
Położenie osoby małoletniej uregulowane zostało przez katalog regulacji wynikających z wielu gałęzi prawa odnoszących się do szczególnej ochrony jego statusu jako dziecka funkcjonującego w rodzinie, społeczeństwie i państwie. Ustanowione prawo stawiało sobie za cel stworzenie wszystkim dzieciom równych szans bez względu na urodzenie, pochodzenie i położenie społeczne. Dążono, przynajmniej w sensie deklaratywnym, do zapewnienia dzieciom m.in. prawa do harmonijnego wychowania w rodzinie a w razie jej braku do opieki ze strony państwa, prawa do nauki na każdym jej szczeblu oraz prawa do ochrony przed wyzyskiem, podejmowaniem pracy zarobkowej przed osiągnięciem odpowiedniego wieku oraz specjalnej ochrony pracy w okresie niepełnoletności dziecka. Mając na względzie ograniczenia wynikające z rozmiarów niniejszego artykułu, przedstawiona analiza koncentruje się wokół najważniejszej zagadnień wynikających z prawa rodzinnego i opiekuńczego obowiązującego w okresie wczesnego PRL-u.

\section{Prawo rodzinne i opiekuńcze}

Jednymi z pierwszych aktów prawnych kształtujących sytuację dziecka w powojennym ustawodawstwie były m.in.: Dekret z 25 września 1945 r. Prawo małżeńskie obowiązujący od dnia 1 stycznia 1946 r., Dekret z 22 stycznia 1946 r. Prawo rodzinne oraz Dekret z 14 maja 1946 r. Prawo opiekuńcze, które zaczęły obowiązywać z dniem 1 lipca 1946 r. W krótkim czasie od wejścia w życie przywołanych dekretów rozpoczęły się prace nad stworzeniem jednolitego aktu prawnego. Dzięki staraniom Komisji Współpracy Prawniczej Polsko-Czechosłowackiej 27 czerwca 1950 r. uchwalony został Kodeks rodzinny (Demokratyczny Przegląd Prawniczy 1949: 30-35). Wskazane akty prawne wprowadzily regulacje znacznie polepszające sytuację prawną dziecka w stosunku do stanu wcześniejszego.

\section{Dzieci malżeńskie i pozamalżeńskie}

Przez wieki jedną z naczelnych zasad kształtujących pozycję dziecka był fakt jego przyjścia na świat w związku małżeńskim i pozamałżeńskim (Płaza 1997: 249). Prawo rodzinne z 1946 roku wprowadzało jeszcze odrębne kategorie dzieci w zależności od sposobu ustalenia ojcostwa, posługując się pojęciami: „dzieci z małżeństwa”, które odnosiło się do małoletnich zrodzonych $\mathrm{w}$ trakcie trwania małżeństwa ich rodziców oraz ,dzieci pozamałżeńskie”, u których ojcostwo mogło być ustalone na drodze powództwa sądowego. Dodatkowo w art. $63 \S 1$ dekret wskazywał na tzw. ,uprawnienie" polegające na uznaniu przez prawo dziecka, które przyszło na świat przed zawarciem związku małżeńskiego jego rodziców, za urodzone w małżeństwie. Ponadto art. $64 \S 1$ niniejszej regulacji ustanawiał możliwość uznania dziecka spoza małżeństwa przez ojca za swoje, tworząc tym samym kategorię „dzieci uznanych”. Ukształtowana została również instytucja tzw. „zrównania” polegająca na tym, że na drodze sądowej dziecko pozamałżeńskie, nieuznane przez ojca, mogło zostać zrównane w prawach z dziećmi małżeńskimi, jeśli z okoliczności sprawy wynikało, że rodzice pozostawali w faktycznej wspólności lub postępowali z nim tak jak z dzieckiem urodzonym w małżeństwie, a więc wspólnie je wychowując (art. 69 
$\S 1$ p.r). Ta kategoria małoletnich została nazwana „dzieckiem zrównanym”. Władza nad małoletnim urodzonym poza małżeństwem, który nie został uznany ani zrównany, przysługiwała tylko matce, bowiem tylko z nią łączył dziecko stosunek pokrewieństwa (art. 62 $\S 1$ p.r.). Inaczej ukształtowana została sytuacja dzieci zrównanych i uznanych, w ich bowiem przypadku zgodnie z treścią art. $73 \S 1$ dekretu, władza rodzicielska należała się temu z rodziców, któremu została ona przyznana przez sąd. Władza rodzicielska nad dziećmi uznanymi i zrównanymi nigdy nie mogła zatem należeć do obojga rodziców. Tylko w przypadku dzieci małżeńskich władza ta przysługiwała obojgu rodzicom pozostającym w związku małżeńskim (art. 20 § 1 p.r.). Poza inaczej ukształtowanymi zasadami sprawowania władzy rodzicielskiej jeszcze jedną sytuacją różnicującą pozycję dzieci małżeńskich i pozamałżeńskich były prawa do spadku po ojcu i członkach jego rodziny, które nie przysługiwały tym ostatnim (Orzeczenie SN 6.X.1951: 41).

W Kodeksie rodzinnym z 1950 roku ostatecznie zrównano pozycję wszystkich dzieci. Symbolicznym zerwaniem z tradycją różnicowania ich sytuacji było całkowite odejście od dotychczasowych pojęć „dzieci z małżeństwa” i „dzieci pozamałżeńskie”. Od tej pory operujemy jedynie terminami: „rodzice i dzieci” (Druk Sejmu Ustawodawczego 1949/1950: 8). Zgodnie z art. II przepisów wprowadzających Kodeks rodzinny, uchylone zostały „wszelkie ograniczenia dotyczące stanowiska prawnego dzieci, które nie pochodzą od męża matki, tj. dzieci pozamałżeńskich" (Szer 1952: 171). Równym prawom i obowiązkom obu kategorii dzieci odpowiadały zatem równe względem nich prawa i obowiązki ich rodziców, niezależnie od tego czy pozostawali oni w związku małżeńskim. Zgodnie bowiem z art. $56 \S 1$ kodeksu władza rodzicielska służyła obojgu rodzicom ex lege, $\mathrm{z}$ chwilą zaś ustalenia ojcostwa, przysługiwała ona ojcu względem dziecka na równi $\mathrm{z}$ matką (art. $56 \S 3$ k.r.). Prawo powojenne za jedną z naczelnych zasad przyjęło zatem, że z samego faktu urodzenia dziecka wynika naturalny stosunek pokrewieństwa pomiędzy nim a jego rodzicami.

\section{Prawa i obowiązi rodziców względem dziecka}

Prawo rodzinne „zrywało” również z wielowiekową regułą odmiennej pozycji ojca i matki w rodzinie. Wcześniejsze regulacje obowiązujące w całej Europie, nawet jeśli dopuszczały matkę do udziału we władzy rodzicielskiej, to w sytuacji braku porozumienia przyznawały pierwszeństwo zdaniu i woli ojca (Makiłła 2008: 404). Wzorując się na prawie radzieckim, polski ustawodawca zrównał w prawach oboje rodziców, zaś w razie różnicy poglądów na istotne sprawy dziecka, prawo do decyzji oddał władzy opiekuńczej (art. $20 \S 2$ p.r.).

Wyrazem równouprawniania rodziców pozostających w związku małżeńskim były również przepisy wskazujące, że rozstrzygają oni wspólnie o istotnych sprawach rodziny, do których należały sprawy związane ze sprawowaniem przez nich władzy rodzicielskiej (art. $20 \S 1$ p.r. oraz art. 15 k.r.). Jednym z ważnych obowiązków małżonków było przyczynianie się do zaspokajania potrzeb rodziny, czyli m.in. łożenia środków na utrzymanie i wychowanie dzieci (art. 15 p.m., art. $18 \S 1$ p.r. oraz art. 18 k.r.). Obowiązek ten nie usta- 
wał nawet wówczas, gdy doszło do czasowego zawieszenia lub odebrania władzy rodzicielskiej (art. 44 § 1 p.r.). W należyty sposób chroniono również interes materialny dzieci, których rodzice nie byli małżonkami. Wskazywano bowiem, że „obowiązek ponoszenia kosztów utrzymania i wychowania dzieci ciąży na obojgu rodzicach" (art. $56 \S 1$ p.r.) do czasu jego pełnego usamodzielnienia (art. 57 § 1 p.r. oraz art. 39 k.r.). Sytuację materialną dzieci zabezpieczało jeszcze szereg innych unormowań, które regulowały kwestię zarządu sprawowanego przez rodziców nad majątkiem należącym do dziecka do czasu uzyskania przez nie pełnoletniości (art. 27-39 p.r. oraz art. 58-59 k.r.).

\section{Pojęcie dobra dziecka}

Po raz pierwszy został skonstruowany nowel model relacji pomiędzy rodzicami a dzieckiem. Zgodnie z art. $20 \S 3$ Prawa rodzinnego oraz art. 54 Kodeksu rodzinnego obowiązkiem rodziców stało się sprawowanie władzy rodzicielskiej tak, jak tego wymaga dobro dziecka. Przyjęto zatem, że naczelną zasadą stosunków pomiędzy rodzicami a ich dziećmi jest zasada ochrony dobra dziecka. W Orzeczeniu z 7 kwietnia 1952 roku Sąd Najwyższy podkreślił, że na tym właśnie polega ,ogromny postęp prawa socjalistycznego w stosunku do prawa burżuazyjnego czy feudalnego, które jeszcze tkwiły całkowicie lub częściowo w pojęciach akcentujących nie obowiązki, lecz prawa rodziców względem dzieci, nie podlegające dostatecznej kontroli i wykonywane w interesie rodziców" (Orzeczenie SN 7.04.1952: 73). Zwyciężyła zatem idea, że władza rodzicielska istnieje przede wszystkim w interesie dziecka, a nie w interesie rodziców. Dla określenia pojęcia dobra dziecka używano zamiennie terminu ,interes dziecka”, który oznaczał sumę jego interesów osobistych i majątkowych (Orzeczenie SN 24.11.1951: 74; Orzeczenie SN 22.12.1951: 33; Orzeczenie SN 13/20.11.1955; Orzeczenie SN 26.04.1958). Rodzic sprawujący władzę rodzicielską w interesie swojego dziecka został zobligowany do kształtowania jego sytuacji w sposób optymalny z obiektywnego punktu widzenia.

Pojęcie dobra dziecka stanowiło również kryterium interesu społecznego (Orzeczenie SN 18.01.1945: 187), który zyskiwał przymiot nadrzędności tylko w szczególnych i nielicznych wypadkach, kiedy to dobro dziecka mogło być ograniczone lub pominięte (Orzeczenie SN 8.11.1957: 117). Dobro dziecka determinowało również sytuację prawną małżonków, którzy dążyli do rozwodu, stanowiąc kluczową przesłankę negatywną do jego orzeczenia. Art. $29 \S 2$ Kodeksu rodzinnego wskazywał na niedopuszczalność rozwodu w przypadku, gdyby miało ucierpieć dobro małoletnich dzieci. Rozwód nie mógł być również orzeczony, gdy żądał go małżonek wyłącznie winny rozkładu pożycia a drugi małżonek nie wyrażał na to zgody (art. $30 \S 1$ k.r.). Wyjątkiem umożliwiającym orzeczenie rozwodu $\mathrm{w}$ takim przypadku była okoliczność wskazująca, że w nieformalnym związku małżonka wyłącznie winnego przyszło na świat dziecko. Zgodnie bowiem ze stanowiskiem wyrażonym w wytycznych Sądu Najwyższego z dnia 26 kwietnia 1952 r., za rozwodem w takiej sytuacji przemawiało „dobro dzieci, które wymaga, by wychowywały się one w trwale istniejącej rodzinie (...). Dobro dzieci jest więc tym szczególnie doniosłym w skali społecznej czynnikiem, który może przeważyć nad wszelkimi zastrze- 
żeniami przeciwko orzeczeniu rozwodu na żądanie małżonka wyłącznie winnego i uzasadnić przyjęcie, że orzeczenie takie wyjątkowo zgodne będzie z interesem społecznym" (Szer 1952: 114-115). W wyroku rozwodowym sąd decydował o tym, któremu rodzicowi powierza wykonywanie władzy rodzicielskiej. Rozstrzygając komu powierza dziecko, był zobligowany „,kierować się nie interesem rodziców, nie jakimikolwiek innymi względami, lecz wyłącznie dobrze rozumianym interesem dziecka (...)" (Orzeczenie SN z 7.06.1950: 158-161). Powierzenie władzy jednemu z rodziców nie oznaczało, że drugi rodzic był jej pozbawiony. Sąd był zobligowany wówczas określić uprawnienia w zakresie nadzoru nad wychowaniem dziecka, temu rodzicowi, który na co dzień nie sprawował nad nim władzy rodzicielskiej (art. 31 p.m., art. $21 \S 2$ p.r. i art. 32 k.r.).

W tak ukształtowanej sytuacji prawnej oboje rodzice, nawet po rozwodzie, nadal decydowali o wychowaniu swojego dziecka. Istniała oczywiście możliwość pozbawiania władzy rodzicielskiej jednego rodzica lub oboje rodziców w przypadku zaistnienia trwałej przeszkody lub rażącego zaniedbania swoich obowiązków albo nadużycia władzy rodzicielskiej (art. 61 k.r.). Pomimo pozbawienia rodzica władzy rodzicielskiej sąd mógł przyznać jemu prawo do utrzymywania z dzieckiem osobistych kontaktów (art. $31 \S 1$ pkt. 4 p.m.).

\section{Prawo do karcenia}

Istotną funkcją władzy rodzicielskiej było kierowanie dzieckiem, które utożsamiać należało z troską o jego fizyczny i psychiczny rozwój. Miało ono ostatecznie doprowadzić do przygotowania dziecka do „pracy dla dobra społeczeństwa, odpowiednio do jego uzdolnień" (art. 35 k.r.). Sprawowanie funkcji wychowawczej zostało ograniczone do takich metod, które nie były sprzeczne z doborem dziecka. W sferze deklaratywnej „odżegnywano" się od tradycji surowego karcenia dzieci. W art. 25 § 2 Dekretu Prawo rodzinne znalazł się jednak przepis, w którym wskazywano, że „rodzice mogą karcić dzieci, będące pod ich władzą, jednak bez szkody dla ich zdrowia fizycznego lub moralnego i w graniach wskazanych celem wychowawczym." W artykule tym po raz ostatni wprost wyrażono prawo rodziców do karcenia dzieci. Tego typu regulacji już nigdy nie powtórzono uznając, że podnosi ona „W istocie karcenie dziecka do rangi uznanego, chociaż ograniczonego atrybutu władzy rodzicielskiej" (Sokołowski 1987: 72).

Nie zmienia to jednak faktu, że przez kolejne dekady wskazywano, że cielesne karcenie dzieci jest niezbędne dla ich dobrego wychowania. W ramach tzw. pozaustawowego kontratypu karcenia małoletnich rodzice mogli stosować wobec dzieci kary fizyczne i psychiczne, jeśli przesłanką zastosowania karcenia był cel wychowawczy, a karcenie zostało zastosowane w wyniku konkretnego przewinienia dziecka oraz ograniczało się do takich postaci, których stopień natężenia i forma nie łączyły się z naruszeniem narządu ciała, rozstrojem czy uszczerbkiem na zdrowiu i nie stanowiły zagrożenia dla prawidłowego rozwoju dziecka, przede wszystkim zaś nie wyczerpywały znamion przestępstwa znęcania się (Andrejew 1964: 79-84). Sąd Najwyższy w orzeczeniu z 1938 roku, które zachowało aktualność również po wojnie uznał, że „rodzicom wprawdzie przysługuje prawo karcenia, jednakże kilkakrotne bicie, którego skutkiem są sińce i podbiegnięcia krwawe z wy- 
broczynami, jest już od strony przedmiotowej znęcaniem się nad dzieckiem i podpada pod art. $246 \mathrm{KK}$, którego stronę podmiotową wypełnia fakt bicia okrutnego" (Orzeczenie SN, OSP 1938, poz. 215.). W ten sposób utrwalone stanowisko powodowało, że karcenie polegające na takim zachowaniu jak: uderzenie dziecka, zamknięcie go w pomieszczeniu, użycie przymusu lub groźby czy wyzywanie go w sposób naruszający jego godność, pomimo iż wypełniało znamiona czynów zabronionych były dozwolone (Różycka-Jaroś 2012: 22-23). Warto zwrócić również uwagę na art. 22 Dekretu Prawo opiekuńcze, w którym umieszczono wyraźny zakaz stosowania karcenia cielesnego przez opiekuna. $\mathrm{W}$ razie potrzeby miał on obowiązek zwrócić się do władzy opiekuńczej, czyli sądu, który mógł zastosować wobec podopiecznego określone w prawie środki wychowawcze. Przepis ten, podobnie jak art. $25 \S 2$ Dekretu Prawo rodzinne, nie został powtórzony w kolejnych regulacjach prawnych. Uznano bowiem, że uniemożliwia on zupełnie nawet wyjątkowe karcenie, zastosowanie zaś środków wychowawczych może wywołać bardziej negatywne skutki uboczne (Sokołowski 1987: 72).

Zaczęto również zadawać pytanie, czy osoby sprawujące czasową opiekę nad dzieckiem, a niebędące jego rodzicami, jak wychowawcy czy nauczyciele, mają takie same uprawnienia do jego karcenia jak rodzice. Pomimo sporu w doktrynie (Gubiński 1961: 67-69) przeważył pogląd, że wyżej wskazane osoby nie mają uprawnień do zastosowania wobec dzieci karcenia fizycznego. Tłumaczono to faktem, że środowiska poza rodziną mają za zadanie kształtować osobowość dziecka tylko w ograniczonym zakresie a główna odpowiedzialność za ten proces spoczywa na rodzicach (Andrejew 1964: 79). Pogląd ten znalazł swoje odzwierciedlenie w aktualnym po wojnie Wyroku Sądu Najwyższego z 1938 roku, który wskazywał: „kto umyślnie zadaje urazy cielesne lub w inny sposób narusza nietykalność cielesną osoby odpowiada za to bez względu na pobudki wychowawcze czy inne, wobec czego użycie przez nauczyciela środków zakazanych przez przepisy, choćby w swoiście pojętych celach wychowawczych, nie jest prawem i nie wyłącza karalności czynu" (Wyrok SN z 17.01.1938 r.).

Podsumowując, stwierdzić należy, że do sfery uprawnień rodzicielskich, pomimo braku wprost wyrażonego zezwolenia, należało prawo do karcenia cielesnego dzieci w ramach ich procesu wychowania, natomiast niniejsze uprawnienie nie przysługiwało co do zasady osobom trzecim.

\section{Zakończenie}

Przedstawiona powyżej analiza określonych regulacji uzmysławia nam, że zasady wypracowane przez prawo rodzinne i opiekuńcze po 1945 roku były na tyle postępowe w stosunku do wcześniej obowiązującego ustawodawstwa, że w dużym stopniu obowiązują we współczesnej rzeczywistości. Najistotniejsza zmiana, jak miała miejsce w Polsce po 1989 roku odnosi się do kwestii braku akceptacji dla karcenia cielesnego dzieci przez ich rodziców. Na regulację, która wprost zakazuje stosowania kar cielesnych polskie dzieci musiały jednak czekać ponad 20 lat. Obecna sytuacja dziecka jest oceniania również przez 
pryzmat fundamentalnej zasady poszanowania jego godności i wszelkich przysługujących mu praw. Kluczowa zasada sprawowania władzy rodzicielskiej w zgodzie z dobrem dziecka, wzmocniona została poprzez zobligowanie rodziców do poszanowaniem jego godności i praw. Ustawodawca dopuścił również bardziej elastyczne rozwiązania prawne w zakresie kształtowania sytuacji prawnej dziecka po rozwodzie rodziców, sankcjonując m.in. możliwość tzw. opieki naprzemiennej.

\section{Literatura}

Andrejew I. (1964), Oceny prawne karcenia nieletnich. Warszawa, Państwowe Wydawnictwo Naukowe.

Demokratyczny Przegląd Prawniczy (1949), nr 8-9.

Gubiński A. (1961), Wyłączenie bezprawności czynu. Warszawa, Wyd. Uniwersytetu Warszawskiego. Makiłła D. (2008), Historia prawa w Polsce. Warszawa, Państwowe Wydawnictwo Naukowe.

Płaza S. (1997), Historia prawa w Polsce na tle porównawczym, cz. I: X-XVIII w. Kraków, Księgarnia Akademicka Wyd. Naukowe.

Różycka-Jaroś S. (2012), Karcenie dzieci - czyn zabroniony czy okoliczność uchylająca bezprawność. Warszawa, Wydawnictwo Uniwersytetu Warszawskiego.

Sokołowski T. (1987), Władza rodzicielska nad dorastającym dzieckiem. Poznań, Wydawnictwo Naukowe Uniwersytetu Adama Mickiewicza.

Szer S. (1952), Prawo rodzinne. Warszawa, Państwowe Wydawnictwo Naukowe.

\section{Akty prawne}

Dekret z dnia 25 września 1945 r. Prawo małżeńskie (Dz. U. 1945 nr 48 poz. 270).

Dekret z dnia 22 stycznia 1946 r. Prawo rodzinne (Dz. U. $1946 \mathrm{nr} 6$ poz. 52).

Dekret z dnia 14 maja 1946 r. Prawo opiekuńcze (Dz. U. 1946 nr 20 poz. 135).

Druk Sejmu Ustawodawczego, 1949/1950 nr 675

Orzeczenie SN, OSP 1938, poz. 215.

Orzeczenie SN z dnia 6.X.1951 r. C 426/51 NP. 1952 nr 1.

Orzeczenie SN z dnia 6.X.1951 r. C 426/51 NP. 1952 nr 1.

Orzeczenie SN z dnia 7.04.1952 NP 1952, z. 8-9.

Orzeczenie SN z dnia 24.XI.1951 r., NP. 1952, z. 8-9.

Orzeczenie SN z dnia 22.XII.1951 r., NP. 1952, z. 7.

Orzeczenie SN z dnia 13/20.XI.1955 r., C 1964/52 OSNCP 1956, poz. 32.

Orzeczenie SN z dnia 26.IV.1958 r., OSNCP 1958, z. 3, poz. 90.

Orzeczenie SN z dnia 18.I.1945 r., NP. 1945 r., z. 5-6.

Orzeczenie SN z dnia 8.XI.1957 r., NP. 1958, z. 9.

Orzeczenie SN z dnia 7.VI.1950 r. nr C 522/50 PiP 1950 nr 11.

Ustawa z dnia 27 czerwca 1950 r. Kodeks rodzinny (Dz. U. 1950 nr 34 poz. 308).

Wyrok SN z dnia 17.I.1938 r., 3K 1529/37 OSP 1938, poz. 417. 